\title{
Structural And Histochemical Changes Of Albino Rat Kidney Under The Effect Of Injectable Contraceptive
}

\author{
Mamdouh A. Ghali \\ Histology Department - Al-Azhar - Faculty of Medicine
}

\begin{abstract}
The choice of safe and effective method for fertility control still under continuous search. So, discovery of structures having long duration of action which made administration by injection was an attractive alternative to oral contraceptives. Medroxyprogesterone acetate emerged from this early work as promising injectable long - acting contraceptive with minimal risk.

This work was planned to evaluate the structural and histochemical changes induced by injectable contraceptive Depo-provera (MPA), on the kidney of adult female Albino rats as well as testing the degree of reversibility of changes that may develop after the arrest of its use.

Thirty adult female Albino rats were used in this work and divided into three equal groups. Group I was used as a control, group II was intramuscularly injected with MPA 4 times $(2.7 \mathrm{mg}$ / rat every 3 oestrus cycles) and sacrificed one day after arrest of the injection, while, group III the animals were injected with MPA by the same dose and sacrificed 30 days after arrest of the injection.

The abdominal aorta was exposed and Indian ink injection was injected to study the renal vascular changes. The animals were sacrificed, the kidney was dissected and paraffin sections were prepared and stained by haematoxylin and eosin and PAS technique to study the microscopic structure and the distribution of PAS+ve materials respectively. Frozen sections were prepared and stained by both Gomori and Nachla's techniques to study the activity of acid phosphatase enzyme and succinic dehydrogenase enzyme respectively. The obtained data were statistically analyzed using Student's t.test.

The injected groups showed atrophy of tubular epithelium, dilatation of tubular lumina. All recovery groups were nearly similar to normal state except PAS+ve material of renal tubules which were nearly similar to injected groups. The treated groups showed significant increase in vascular distribution and PAS+ve materials. While, non significant changes were noticed in the activity of acid phosphatase and succinic dehydrogenase enzymes.

It was concluded that there are reversible structural and histochemical changes in the rat kidney under the effect of MPA. So, the use of MPA could be considered as a safe contraceptive method.
\end{abstract}

\section{Introduction}

The need for effective, safe and easy method of contraception has not diminished with the advance in the different contraceptive methodology. Oral administration of contraceptives results in immediately high blood hormones that decrease with time and repetitive doses must be given at frequent intervals to keep the blood levels within the effective range. So, studies have been performed to find a suitable long acting hormonal contraceptive to avoid the adverse effects of oral pills which may be due to its estrogen component.

Medroxyrogesterone acetate (MPA) was first used for treatment of habitual abortion and endometriosis (Kennedy, 1978). Using a single dose of MPA (1-4 $\mathrm{gm})$, for the treatment of premature labor was found to protect against pregnancy for 12 to 24 months (Coutinho and De Souza, 1966). MPA emerged from the early research as a promising injectable contraceptive 
under the trade name (Depo - provera). It is the dopot form of progestin which is derived from the natural progesterone hormone. Fahmy (1976), reported that, MPA inhibited the ovulation through an action on the hypothalamus, resulting in inhibition of $\mathrm{L} \mathrm{H}$ synthesis or release.

MPA has a higher use effectiveness than any reversible method (Nash, 1975) and is provided at 3 months interval (world health organization, 1978). MPA effectiveness continues if the user is a few weeks late in obtaining a repeat injection (Mishell et al., 1968). MPA does not suppress lactation and is suitable for breast feeding leading to low rates of infant morbidity and mortality in the developing world (Karim et al., 1971). Oligomenorrhea and secondary amenorrhea following its use decrease iron deficiency anaemia incidence. It is effective hormone because of its few metabolic side effects (Nash, 1975). It is preferred with special medical needs and when sterilization is not legal or desired.

The present study aimed to study the structural and histochemical changes induced by injectable contraceptive (MPA), on the kidney of female albino rats as well as testing the degree of the reversibility of these changes

\section{Material And Methods}

Thirty adult female Albino rats (150 $200 \mathrm{gm} / \mathrm{B}$.W.) were used and divided into 3 equal groups : Group I (control group) the animals were injected with the same dose of the vehicle, Group II (treated group) the animals were injected intramuscularly 4 times every 3 oestrus cycles with MPA (Medroxyprogesterone acetate), at a dose of $2.7 \mathrm{mg} / \mathrm{rat}$ (Paget and Barnes, 1964). MPA was dissolved in $0.5 \mathrm{ml}$ saline, and the animals were sacrificed one day after the arrest of injection. Group III (recovery group) the animals were injected with the same dose of MPA but sacrificed 30 days after arrest of the injection. The animals were kept for 21 days for detection of any possible pregnancy by the aid of vaginal smear.

Indian ink $(2.5 \mathrm{ml})$ was injected in the abdominal aorta. Renal tissues were fixed in Bouin's solution (Clayden, 1971). Paraffin sections were prepared to study the possible vascular renal changes in the different groups of the study. Neutral buffered formol (10\%) was used to prepare paraffin sections for morphological studies using hoematoxylin and eosin (Drury and Wallington, 1980) and periodic acid Schiff technique (Pearse, 1975). Frozen sections were prepared and histochemically stained by Gomori technique (Gomori, 1941) and Nachla's technique (Nachla et al., 1957) for the localization of the activity of both acid phosphatase and succinic dehydrogenase enzymes.

Calculation of the area percentage of the vascular supply filling by casting technique and estimation of optical densities of the different enzymatic activities were done by the computer image analyzing system using a special soft ware program (Optimas. 6-1). The obtained data were tabulated and statistically analyzed.

\section{Results}

1- Morphological changes in the renal tissue (Fig. 1, $2 \& 3$ ).

The treated group showed epithelial tubular atrophy, dilated lumina of the tubules and vascular dilatation in the renal tissue in comparison with the control group. While in recovery group, these changes returned back to its normal state.

2- Vascular changes in the renal tissue (Fig. 4, 5, 6\& 14; tab .1).

In the treated group, it was observed that the mean vascular area was $(56.33 \pm$ 5.68).

Statistically, it was of significant increase when compared with that of the control group $(35.32 \pm 6.92)$. The vascular supply in the recovery group showed non significant changes when compared with the control.

3- Changes in PAS + ve material in the renal tissue (Fig. 7, 8, 9, $15 \& 16$; tab. 2 \& 3)

In renal glomeruli of the treated group there was significant increase in the mean PAS + ve material $(1.28 \pm 0.05)$ when compared with that of the control group 


\section{Mamdouh A. Ghali}

$(1.03 \pm 0.06)$. After 30 days of the arrest, there was complete return to the normal state. Changes in the renal tubules showed significant increase in the mean PAS + ve material of the treated group $(1.55 \pm 0.05)$ while not returned to control state.

4- Changes in the activity of acid phosphatase enzyme in the renal tissue (Fig. 10, 11, $17 \&$ 18; tab. $4 \&$ 5).

It was observed that renal glomeruli showed non significant change in the activity of acid phosphatase enzyme in the treated group $(0.85 \pm 0.20)$ when compared with the control $(0.85 \pm 0.04)$. The activity of the acid phosphatase enzyme in the renal tubules showed non significant change in the treated group $(1.32 \pm 0.11)$ when compared with that of the control group.

5- Changes in the activity of succinic dehydogenase enzyme in the renal tissue (fig. 12, 13, 19\& 20; tab. $6 \&$ 7).

It was observed that renal glomeruli showed non significant change in the activity of succinic dehyrogenase enzyme in the treated group $(0.40 \pm 0.07)$ when compared with the control $(0.41 \pm 0.14)$. The activity of the succinic dehydrogenase enzyme in the renal tubules showed non significant change in the treated group (1.02 \pm 0.19 ) when compared with that of the control group.

\section{Legand Of Figures}

Fig.-1 A photomicrograph of a section in the control rat kidney, showing normal renal structure.

(Hx. \& E. stain X 500)

Fig.-2 A photomicrograph of a section in the rat kidney injected with MPA one day after the arrest of the treatment, showing dilated tubular lumen with epithelial atrophy of the tubules.

(HX. \& E. stain X 500).

Fig.-3 A photomicrograph of a section in the rat kidney injected with MPA 30 days after the arrest of the treatment, showing normal renal structure.

(Hx. \& E. stain X 500).

Fig.-4 A photomicrograph of a section in the control rat kidney, showing the normal vascular distribution in the different renal tissues.

(Indian ink injection X 250).

Fig.-5 A photomicrograph of a section in the rat kidney just after the arrest of injection of MPA, showing increased vascular distribution in the different renal tissues.

(Indian ink injection X 250).

Fig.-6 A photomicrograph of a section in the kidney 30 days of the arrest of MPA, injection showing return to the normal renal vascularity.

(Indian ink injection X 250).

Fig.-7 A photomicrograph of a section in the control rat kidney, showing the normal distribution of PAS +ve materials in the different renal structures. (PAS reaction $X$ 500)

Fig.-8 A photomicrograph of a section in the rat kidney injected with MPA, one day after the arrest of treatment showing increased PAS +ve reaction in proximal \& distal convoluted tubules and Bowman's capsule.

(PAS reaction X 500).

Fig.-9 A photomicrograph of a section in the rat kidney injected with MPA, 30 days after the arrest of the treatment, showing the distribution of PAS +ve materials in the glomerulus, proximal and distal convoluted tubules.

(PAS reaction X 500).

Fig.-10 A photomicrograph of a section in the control rat kidney showing the normal distribution of acid phosphatase enzyme activity in the different renal structures. (Gomori technique X 250).

Fig.-11 A photomicrograph of a section in the rat kidney injected with MPA, showing no change in the distribution of acid phosphatase enzyme activity.

(Gomori technique X250).

Fig.-12 A photomicrograph of a section in the control rat kidney, showing the normal distribution of succinic dehydrogenase enzyme activity in the kidney. (Nachla's technique X250).

Fig.-13 A photomicrograph of a section in the rat kidney, just after the arrest of injection of MPA, showing no change in the succinic dehydro-genase enzyme activity. (Nachla's technique X125). 


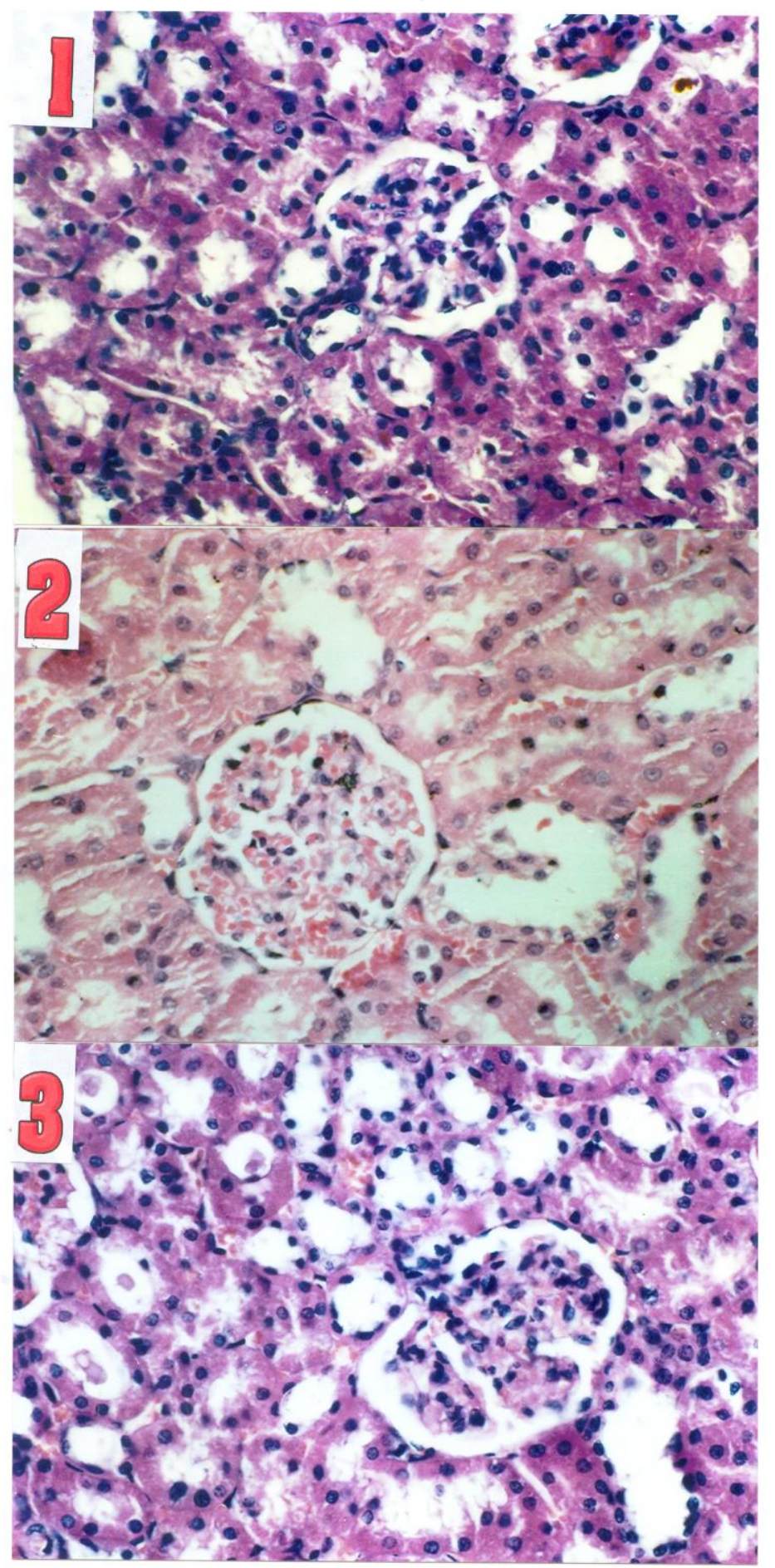




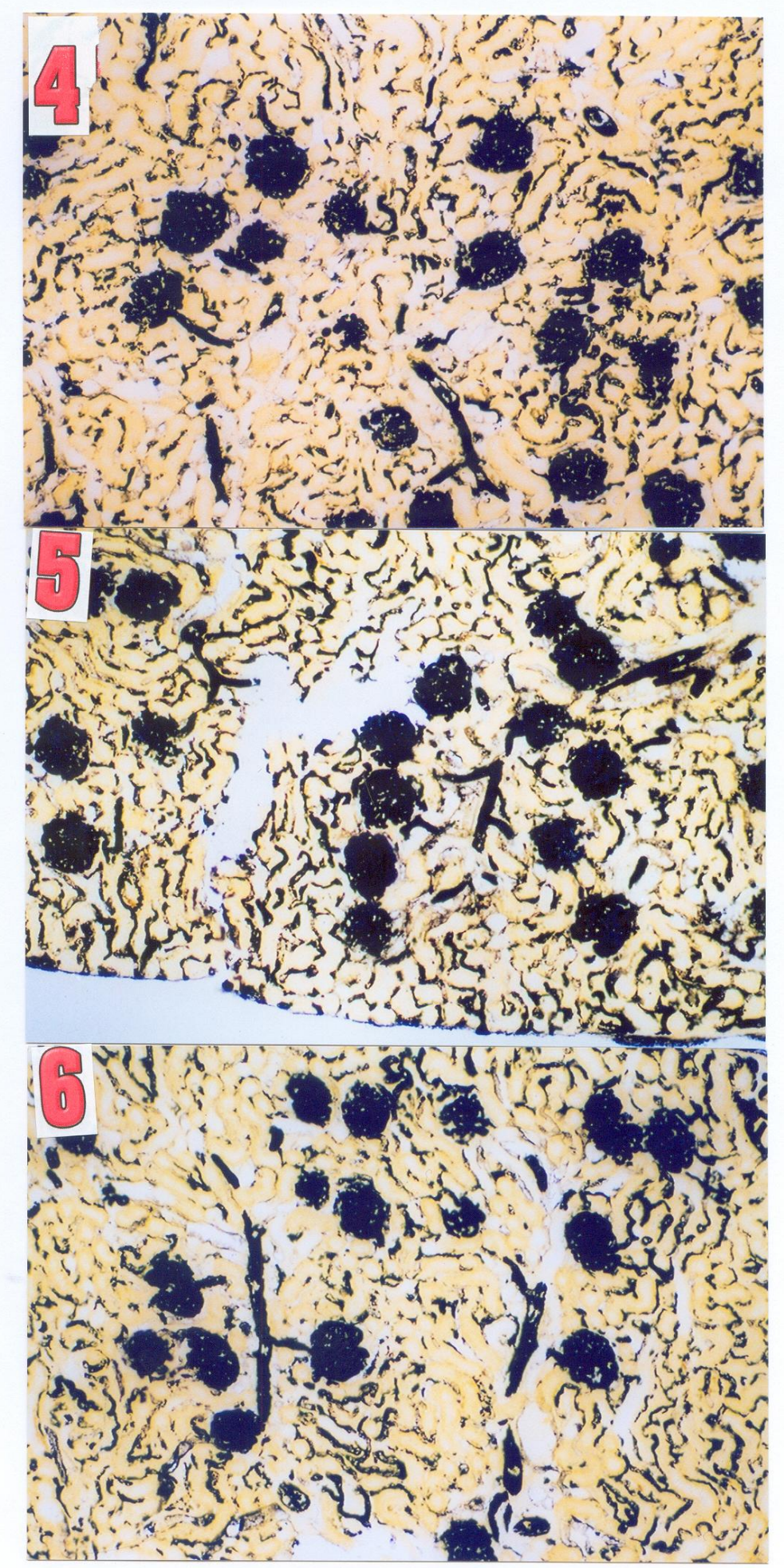




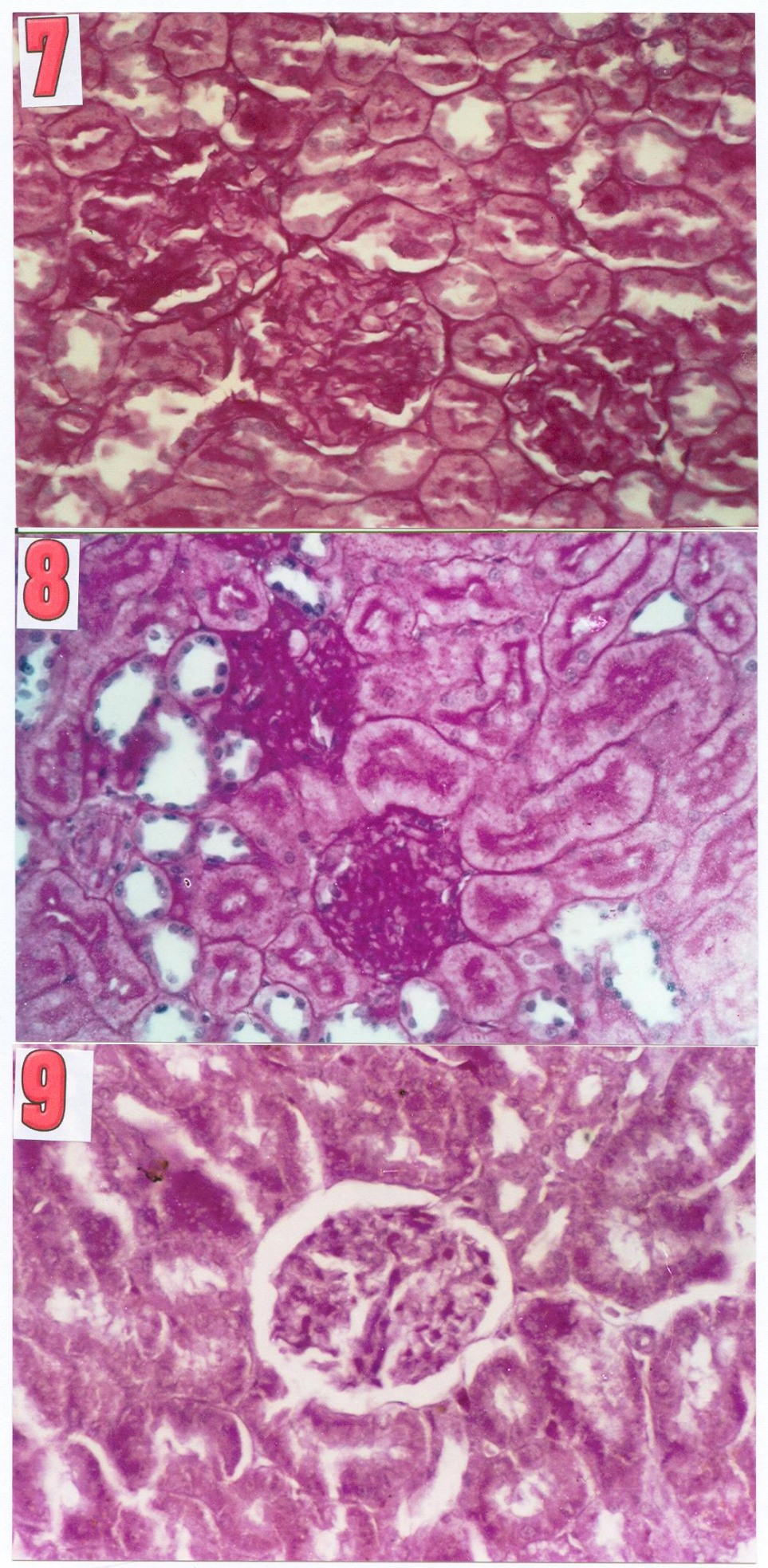




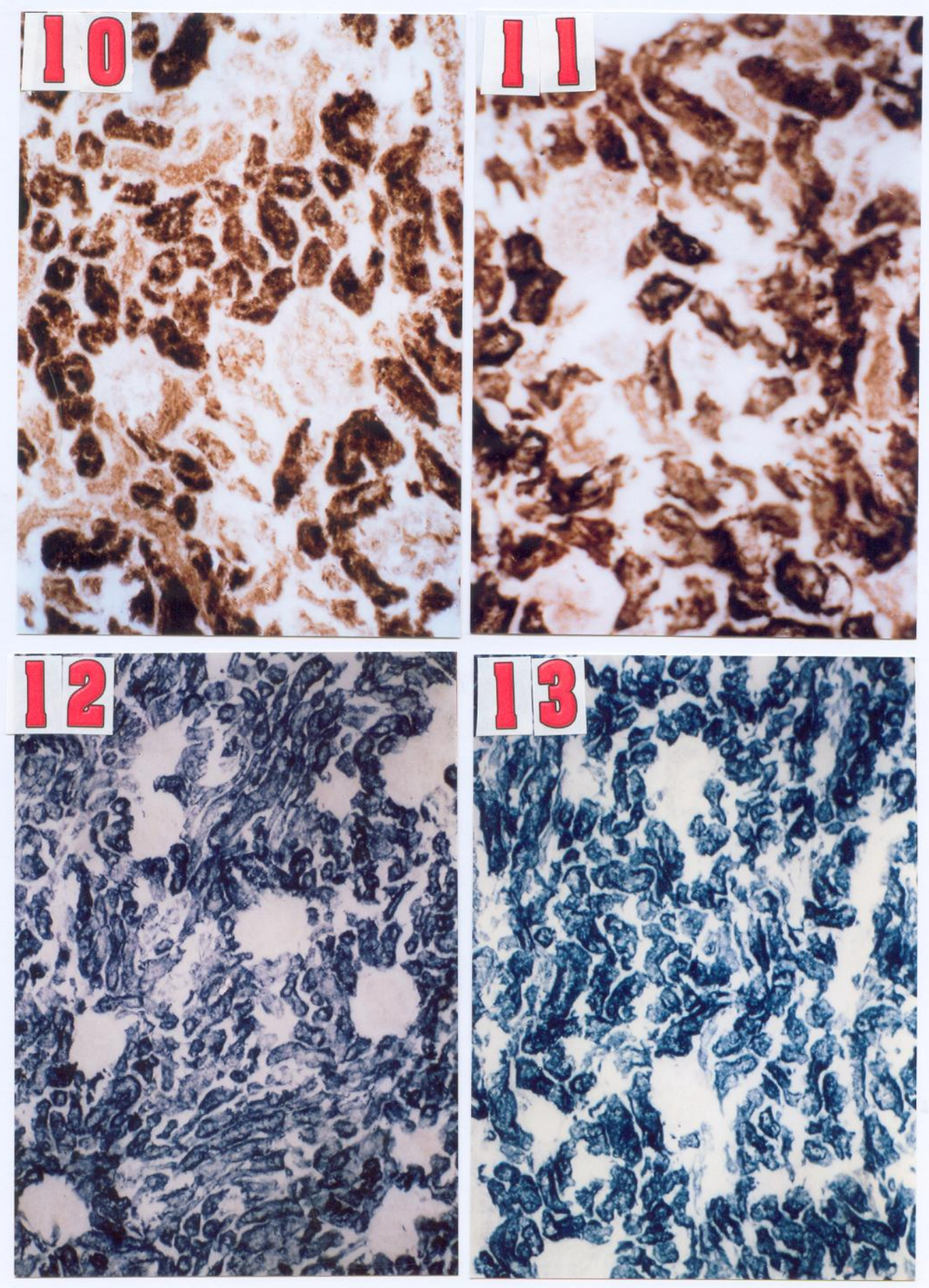


(Tab.1) :- Changes in renal vasculature under the effect of injectable Contraceptive

\begin{tabular}{||c|c|c|c||}
\hline & Group 1(control) & Group 2 & Group 3 \\
\hline Mean 1 & 33.87 & 58.31 & 23.65 \\
\hline 2 & 32.54 & 58.61 & 30.53 \\
\hline 3 & 32.1 & 59.69 & 38.6 \\
\hline 4 & 29.91 & 5815 & 38.88 \\
\hline 5 & 49.07 & 44.88 & 28.36 \\
\hline 6 & 34.42 & 57.33 & 31.85 \\
\hline final mean & 35.32 & 56.33 & 30.98 \\
\hline SD & 6.92 & 5.68 & 4.96 \\
\hline SE & 2.82 & 2.32 & 2.03 \\
\hline T test & 5.74 & 1.248 \\
\hline Sig. & & S.inc & N.S \\
\hline
\end{tabular}

(Tab.2):- Changes in renal glomeruli PAS postive material under the effect of injectable Contraceptive

\begin{tabular}{||c|c|c|c||}
\hline & Group 1(control) & Group 2 & Group 3 \\
\hline Mean 1 & 1.1 & 1.23 & 1.16 \\
\hline 2 & 0.97 & 1.31 & 1.06 \\
\hline 3 & 1.05 & 1.37 & 0.6 \\
\hline 4 & 0.98 & 1.26 & 0.49 \\
\hline 5 & 1.08 & 1.27 & 1.09 \\
\hline 6 & 0.98 & 1.26 & 1.06 \\
\hline final mean & 1.03 & 1.28 & 0.91 \\
\hline SD & 0.06 & 0.05 & 0.29 \\
\hline SE & 0.02 & 0.02 & 0.12 \\
\hline T test & & 8.303 & 0.976 \\
\hline Sig. & & S.I & N.S \\
\hline
\end{tabular}

(Tab.3) Changes in renal tubules PAS postive material under the effect of injectable Contraceptive

\begin{tabular}{||c|c|c|c||}
\hline & Group 1(control) & Group 2 & Group 3 \\
\hline Mean & 1.37 & 1.5 & 1.45 \\
\hline 2 & 1.24 & 1.58 & 1.5 \\
\hline 3 & 1.32 & 1.64 & 1.39 \\
\hline 4 & 1.25 & 1.53 & 1.51 \\
\hline 5 & 1.35 & 1.54 & 1.49 \\
\hline 6 & 1.25 & 1.53 & 1.47 \\
\hline final mean & 1.3 & 1.55 & 1.47 \\
\hline SD & 0.06 & 0.05 & 0.04 \\
\hline SE & 0.02 & 0.02 & 0.02 \\
\hline T test & & 8.303 & 5.83 \\
\hline Sig. & & S.I & S.I \\
\hline
\end{tabular}




\section{Mamdouh A. Ghali}

(Tab.4) Changes in renal glomeruli acid phospatase activity under the effect of injectable Contraceptive

\begin{tabular}{||c|c|c|c|}
\hline & Group 1(control) & Group 2 & Group 3 \\
\hline Mean 1 & 1.38 & 1.32 & 1.28 \\
\hline 2 & 1.43 & 1.21 & 1.29 \\
\hline 3 & 1.44 & 1.5 & 1.51 \\
\hline 4 & 1.4 & 1.4 & 1.3 \\
\hline 5 & 1.57 & 1.26 & 1.22 \\
\hline 6 & 1.01 & 1.24 & 1.35 \\
\hline final mean & 1.37 & 1.32 & 1.33 \\
\hline SD & 0.19 & 0.11 & 0.1 \\
\hline SE & 0.08 & 0.05 & 0.04 \\
\hline T test & & 0.28 & 0.32 \\
\hline Sig. & & NS & NS \\
\hline
\end{tabular}

(Tab.5) Changes in renal tubules acid phospatase activity under the effect of injectable Contraceptive

\begin{tabular}{||c|c|c|c|}
\hline & Group 1(control) & Group 2 & Group 3 \\
\hline Mean 1 & 0.86 & 0.98 & 1.15 \\
\hline 2 & 0.84 & 1.06 & 0.98 \\
\hline 3 & 0.86 & 0.88 & 0.66 \\
\hline 4 & 0.9 & 0.55 & 0.78 \\
\hline 5 & 0.8 & 0.99 & 0.55 \\
\hline 6 & 0.81 & 0.66 & 0.93 \\
\hline final mean & 0.85 & 0.85 & 0.84 \\
\hline SD & 0.04 & 0.2 & 0.22 \\
\hline SE & 0.01 & 0.08 & 0.09 \\
\hline T test & & 0.46 & 0.49 \\
\hline Sig. & & NS & NS \\
\hline
\end{tabular}

(Tab.6) Changes in renal glomeruli suc.dehyd. activity under the effect of injectable Contraceptive

\begin{tabular}{||c|c|c|c||}
\hline & Group 1(control) & Group 2 & Group 3 \\
\hline Mean 1 & 0.91 & 0.92 & 0.97 \\
\hline 2 & 1.22 & 1.3 & 0.87 \\
\hline 3 & 0.96 & 1.2 & 0.98 \\
\hline 4 & 0.99 & 0.81 & 0.88 \\
\hline 5 & 1.2 & 1.02 & 1.21 \\
\hline 6 & 0.82 & 0.87 & 1.12 \\
\hline final mean & 1.02 & 1.02 & 1.01 \\
\hline SD & 0.16 & 0.19 & 0.13 \\
\hline SE & 0.07 & 0.08 & 0.06 \\
\hline T test & & 0.48 & 0.45 \\
\hline Sig. & & NS & NS \\
\hline
\end{tabular}


(Tab.7) Changes in renal tubules suc.dehyd. activity under the effect of injectable Contraceptive

\begin{tabular}{|c|c|c|c||}
\hline & Group 1(control) & Group 2 & Group 3 \\
\hline Mean 1 & 0.25 & 0.3 & 0.4 \\
\hline 2 & 0.33 & 0.45 & 0.38 \\
\hline 3 & 0.55 & 0.5 & 0.51 \\
\hline 4 & 0.62 & 0.4 & 0.4 \\
\hline 5 & 0.39 & 0.36 & 0.36 \\
\hline 6 & 0.34 & 0.37 & 0.31 \\
\hline final mean & 0.41 & 0.4 & 0.39 \\
\hline SD & 0.14 & 0.07 & 0.07 \\
\hline SE & 0.06 & 0.03 & 0.03 \\
\hline T test & & 0.37 & 0.35 \\
\hline Sig. & & NS & NS \\
\hline
\end{tabular}

(fig.14) Changes in renal vasculature under the effect of injectable Contraceptive

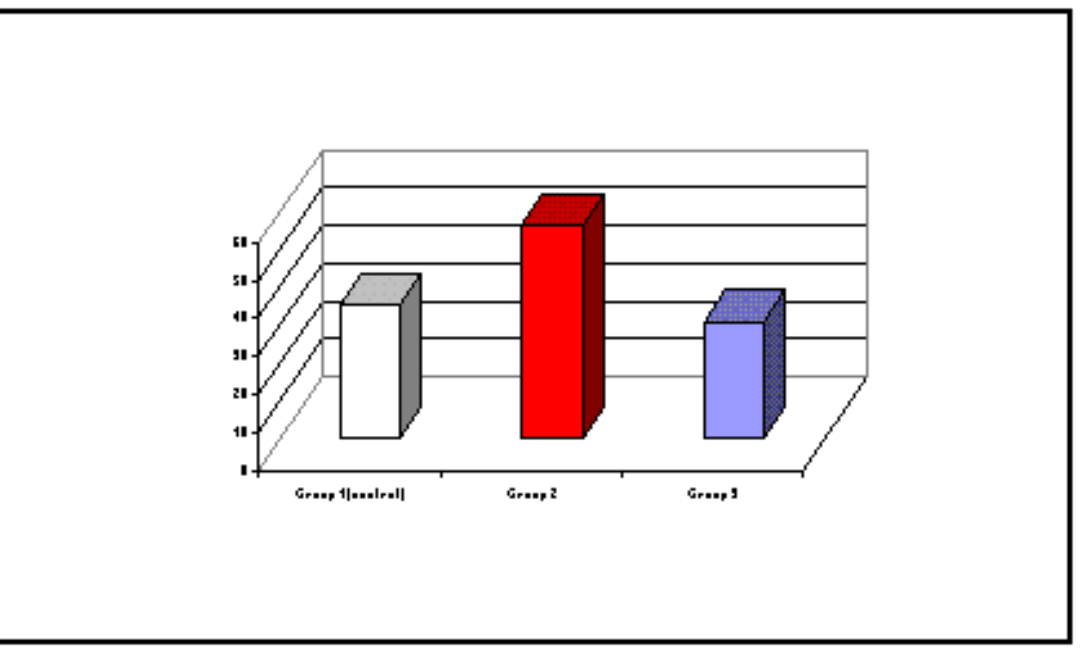

(fig.15) Changes in renal glomeruli PAS postive material under the effect of injectable Contraceptive

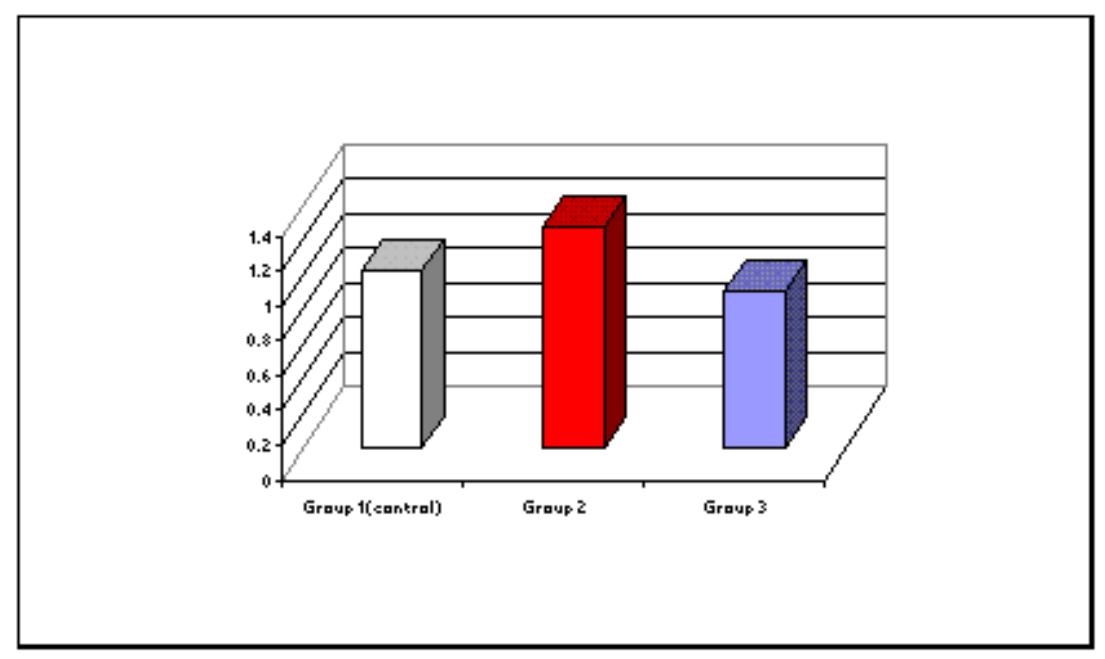


(fig.16) Changes in renal tubules PAS postive material under the effect of injectable Contraceptive

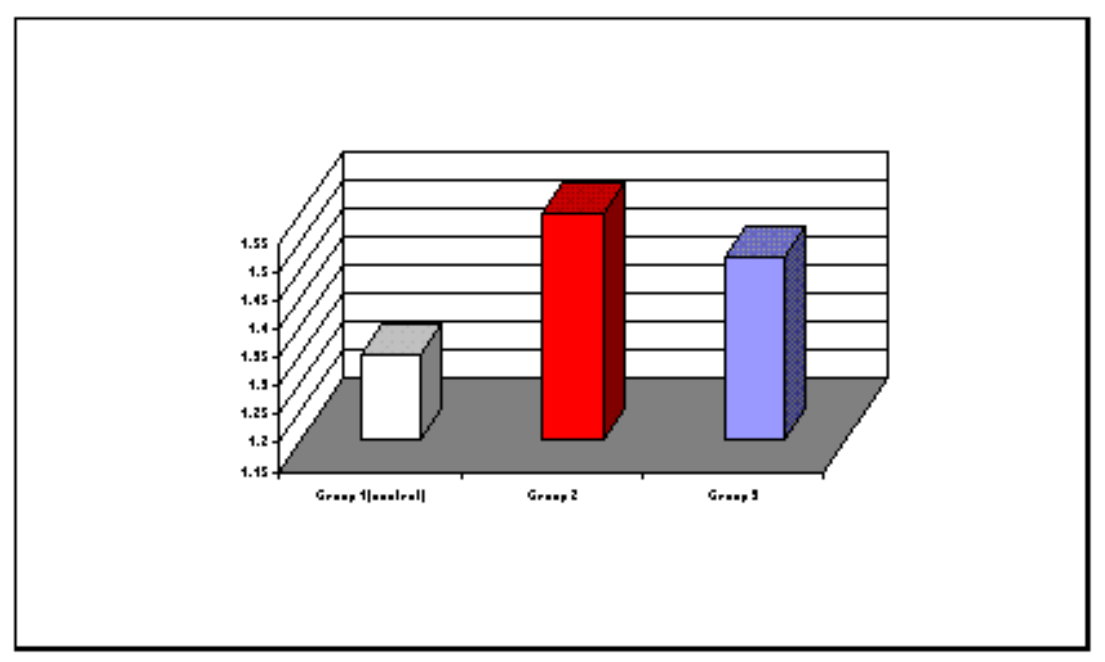

(fig.17) Changes in renal glomeruli acid phospatase activity under the effect of injectable Contraceptive

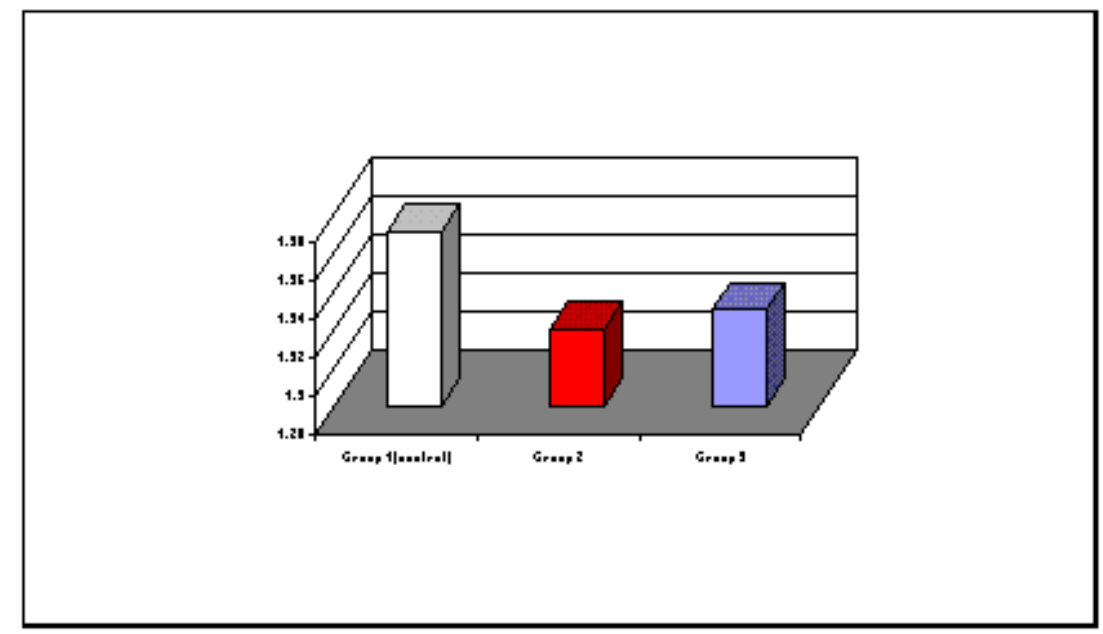

(fig.18) Changes in renal tubules acid phospatase activity under the effect of injectable Contraceptive

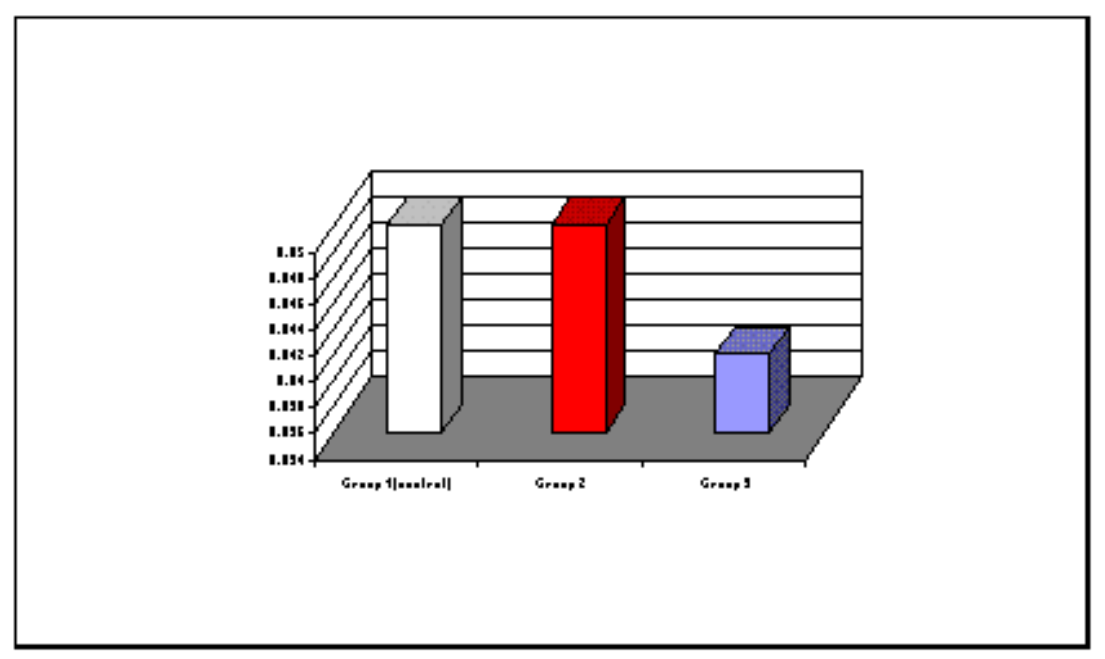


(fig.19) Changes in renal glomeruli suc.dehyd. activity under the effect of injectable Contraceptive

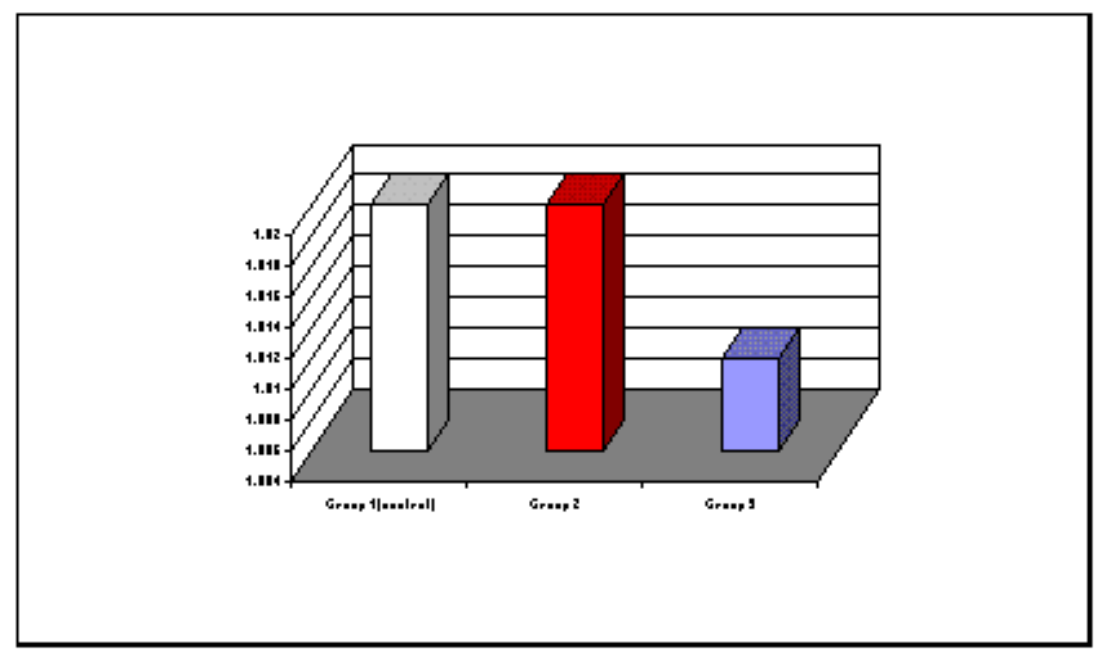

(fig.20) Changes in renal tubules suc.dehyd. activity under the effect of injectable Contraceptive

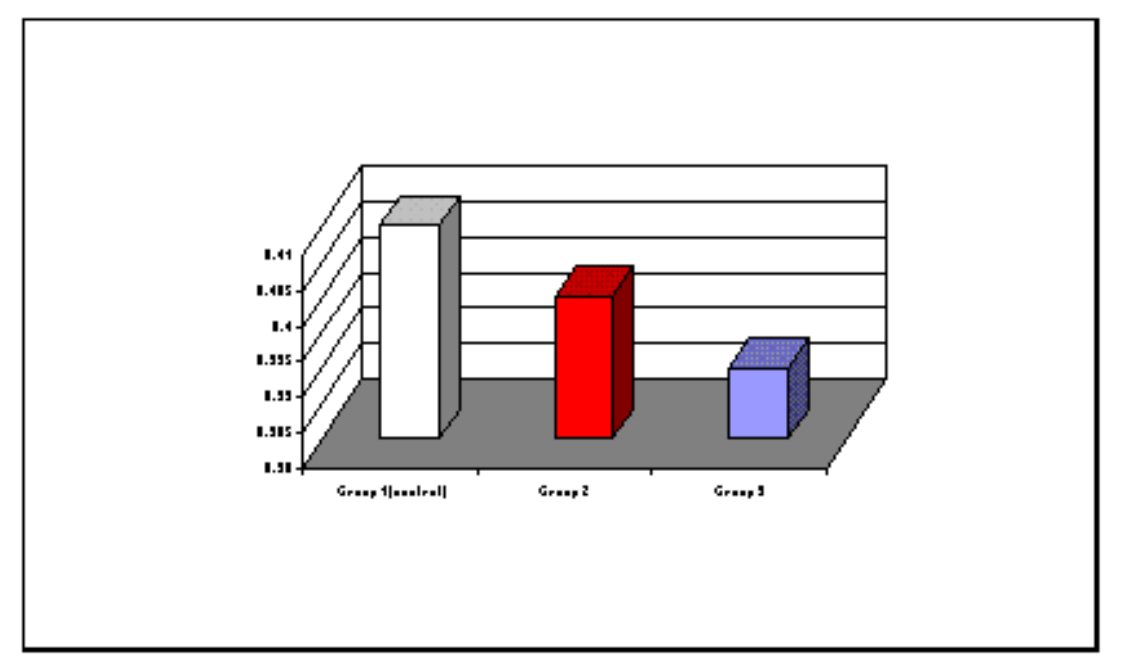

\section{Discussion}

The kidney as one of the highly active and vital organs which is affected by most of the drugs. It is the main organ responsible for excretion of the metabolic products of the hormones. The present work was designed to evaluate the effect of injectable contraceptive, Medroxyprogesterone acetate on the renal tissue.

\section{Structural and vascular changes:}

In our present study, it was observed atrophy of tubular epithelium and dilatation of tubular lumina as well as an increase in the vascular supply in the treated group. According to Fawcett (1994), tissues are composed of parenchymal cells, which carry out the function of the tissue, plus supportive elements e.g. connective tissue and blood vessels which transport metabolites to parenchymal cells. So, structural changes may be considered secondary to the vascular changes. Atrophy of tubular epithelium may be due to the effect of hormone on the cell membrane permeability or integrity causing disturbance in the equilibrium between intrac- 


\section{Mamdouh A. Ghali}

ellular and extracellular fluids (Hashish et al., 1973).

\section{Histochemical Changes:}

The observed increase of PAS + ve materials in the treated group is in agreement with that of Matute and kalkhoff (1972) who suggested that, sex hormones suppress hepatic gluconeogenesis and promote liver glycogen deposition. But, Attia et al. (1994) observed focal depletion of glycogen in liver lobules. Keenan et al. (1970) attributed this depletion to disturbance of Golgi complex in polysaccharide synthesis and that result also reflects the lost capacity of the cells to metabolize and store glycogen. While, Vermuelen and Thiery (1974) found non significant change in carbohydrate metabolism who attributed this change to the very weak corticosteroid like effect of MPA. The structural, vascular and PAS+ve materials recovery changes indicate the possible reversibility of renal function which may be an interval dependent and may be due to the low oxygen tension of the kidney tissue (Junqueira and carneiro, 2003).

The results of this study showed non significant changes in the acid phosphatase activity in both treated and recovery groups. The enzyme reaction is positive only with the permeable membrane and may depend on level of the progesterone which affects permeability of lysosomal membranes (Bitenski and Cohen, 1965). Our results are in accordance with those of El-Kasaby (1987) in the early period of his study which was on blood cells and haemopoietic organs, but his recovery group showed marked decrease in the enzyme activity. This difference may be due to variable sensitivity of the selected organs to MPA and variable concentration and activity of the enzyme in these organs. Also, our results are in agreement with the endometrium results of Boseila et al. (1985), who attributed their results to absence of oestrogen in the single hormone contraceptive because double hormone contraceptive produced marked decrease in the enzyme activity. It was also found that there were non significant changes in succinic dehydrogenase enzyme activity which plays an important role in the respiratory process of most living cells (Novikoff and Essner, 1966). It seems that the played role of MPA still needs further enzymatic studies.

In conclusion, the quantitative changes, observed in the different groups run parallel with the structural and histochemical changes in this study and the effect of MPA on these changes in the rat kidney are clearly reversible which may indicate the safety use of MPA.

\section{References}

1- Attia, M.A.; Ahmed, A.T.; Soas, S.A. and Sadia, R, D. (1994): Effect of combined administration of estrogen and progesterone on the histological and histochemical features of liver and spleen in female non lactating rats. Assiut Vet. Med. J., 31 : 62.

2- Bitenski, L. and Cohen, S. (1965): The variation of endometrial acid phosphatase activity with the menstrual cycle. J. Obstet. And Gynecol. Brit. Comm., 72: 769.

3- Boseila, A. A.; Ragab, A. H., Saleh, N. A.; Hassan, M. I. and Bayomi, A.M. (1985): Histological localization of acid phosphatase enzyme activity in the endometrium of female albino rat under the effect of contraceptives. Egypt J. Histol., 8(2): 249.

4- Clayden, E.G. (1971): Practical sections cutting and staining. Churchill Livingstone, Endinburgh and London, P.371.

5- Coutinho, E.M. and DeSouza, j.C. (1966): Conception control by monthly injection of medroxyprogesterone suspension and a long acting oestrogen. J.Reprod. Fertil. P.209.

6- Drury, R.A and Wallington, B.C. (1980): Carleton's histological technique $5^{\text {th }}$. ed. Oxford University Press. London, New York. Toronto.

7- El-Kasaby, A.N. (1987): Effects of certain contraceptives on blood cells and some haemopoietic organs in albino rat $\mathrm{Ph}$. D. Thesis in Med. Sci. Histol., Al-Azhar Univ.

8- Fahmy, N.M. (1976): Effect of some contraceptives on ovarian function. Ph.D. Thesis, Fac. Of Sci, Cairo Univ.

9- Fawcett, D. (1994): A Text Book of Histology, Philadelphia London, Toronto, Toko and Hong Kong. Chapter 17, p. 479.

10- Gomori, G. (1941): Microtechnical demonstration of phosphatases in the tissue 
sections.Proc. Soc. Exptl. Biol. New York., 42: 23. (Cited by Shon and Totada, 1970).

11- Hashish, S.E.; Ibrahim, H.A. and Wadie, A.F. (1973): Arab J. of Nuclear Sci. and Applic., 6: 101.

12- Junqueira, L.C. and carneiro, J. (2003): kidneys, Basic Histology, Text Book, Lange Medical Books / Mc Graw - Hill, 10th ed.Ch. 19, p.383.

13- Karim, M.; El-Mahgoub, S.; ElGanzoury, B.; Ammar, R.; Yaseen, S. and Fikri, F. (1971): "Evaluation of deladroxate as a monthly contraceptive injection". Ain Shams Med. J. Vol. 22: 343.

14- Keenan, T.W.; Morre, J. and Checetham, R.D. (1970): Lactose synthesis by a Golgi apparatus fraction from rat mammary gland. Nature, 228: 1105.

15- Kennedy, D. (1978): Commissioner FDN, statement before the select committee on population. House of Representatives, August, 8.

16- Matute, M.L. and Kalkhoff, R.K. (1972): Sex steroid influence on hepatic gluconeogenesis and glycogen formation. Endocrinology, 92(3): 762.

17- Mishell, D. R.; El-Habashy M.A.; Good R.G. and Moyer, D.L. (1968): Contraception with an injectable progestin: A study of its use in post-partum women. Am. J. Obst. \& Gynec., 101: 1046.
18- Nachla, M. M.; Isou, K. C.; DeSouza, E. D.; Chen, C. S. and Seligman, A.M. (1957): Cytochemical demonstration of succinic dehydrogenase by the use of a new. Pnitrophenyl substitute ditetrazole. J. Histochem. Cytochem, 5: 420.

19- Nash. H. (1975): Depo-provera. A review. Contraception, Vol. 12: 377.

20- Novikoff, A. and Essner, E. (1966): The liver cell, some new approach to its study. Am. J .Medicine, 29: 102.

21- Paget, G.E. and Barnes, J.M. (1964): In: "Evaluation of Drug Activities Pharmacometrics". Vol. I, 135, (D.R. Laurence and A.L. Bacharach eds). Academic Press, London and New York.

22- Pearse, A.G. (1975): Histochemistry Theoretical and Applied, Vol I 3rd ed. P 150, Williams and Wilkins Co., Baltimare, London and New York.

23- Rosenfield, A.G. (1974): Injectable long acting progestogen contraception: A neglected modality. Am. J. Obstet Gyecol, 120: 537.

24- Vermuelen, A. and Thiery, M. (1974): Hormonal contraceptives and carbohydrate tolerance. Il Influence of MPA and chronic oral contraception, 10: 253.

25- World Health Organization (1978): "Multi national comparative clinical evaluation of two long acting injectable contraceptive steroids, NET. EN and DMPA." Contraception, 17: 395. 


\title{
التغيرات التركيبية والهستوكيميائية فى كلى الجرذ الأبيض تحت تأثير حقن

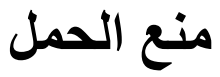

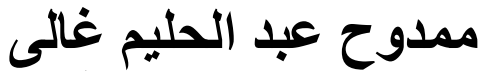 \\ قسم الهستولوجيا - كلية طب الأزهر (بنين)
}

لا يز ال البحث جاريا من أجل إيجاد طريقة آمنة وفعاله في مجال تتظيم النسل .

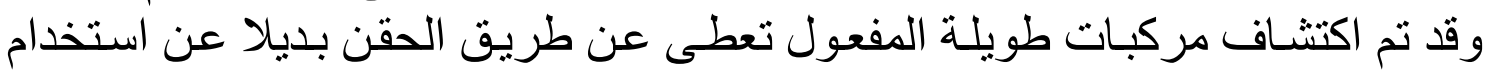

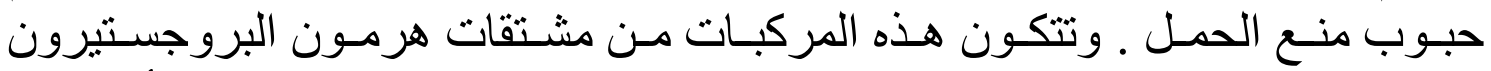

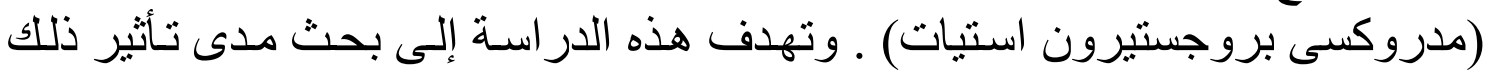

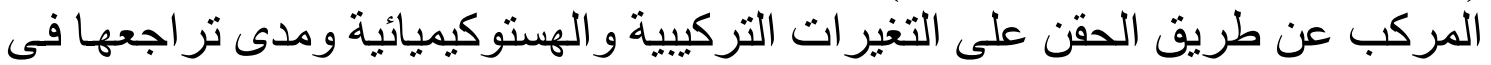

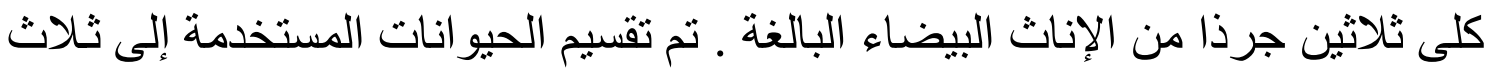

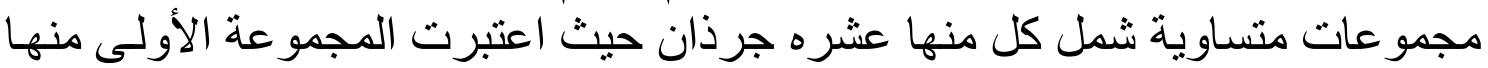

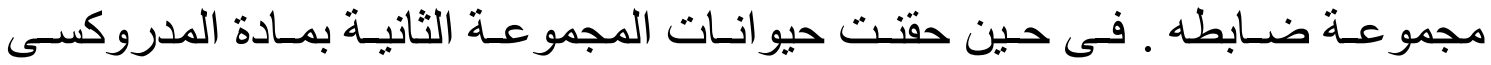

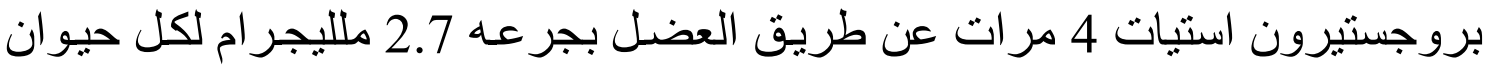

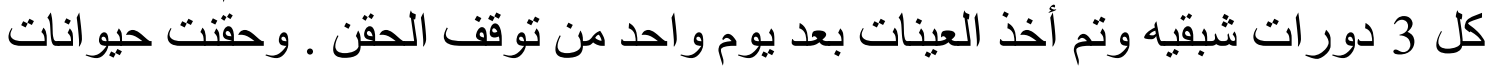

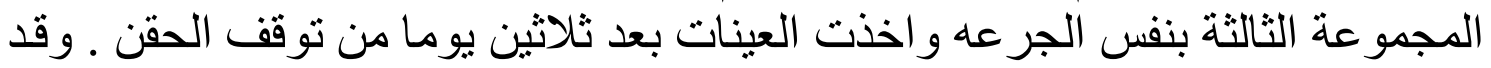

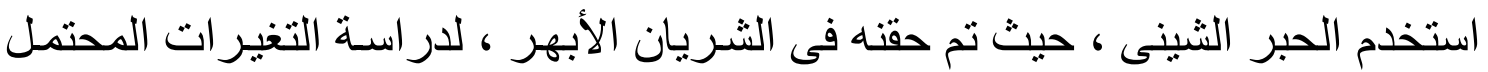

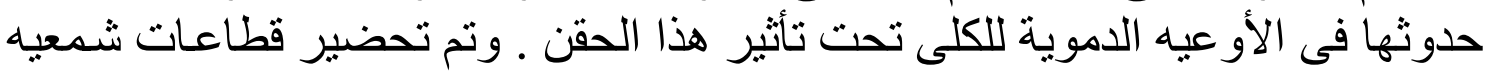

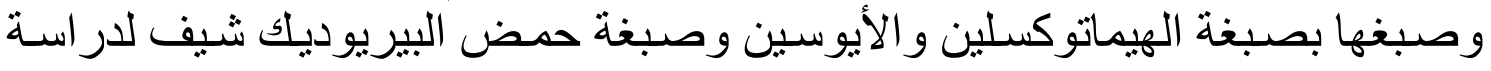

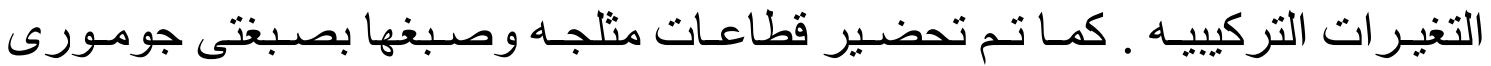

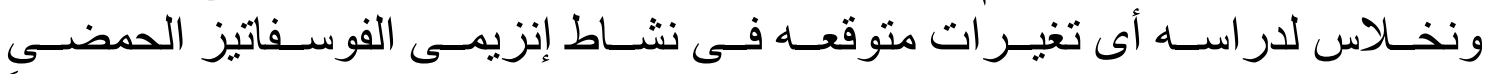

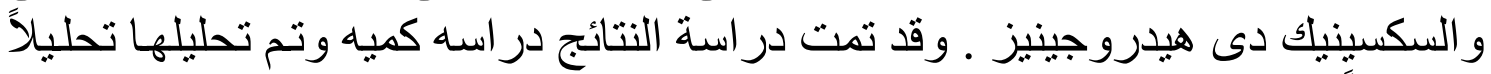

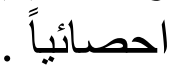
وقد دلت النتائج على ما يلى :-

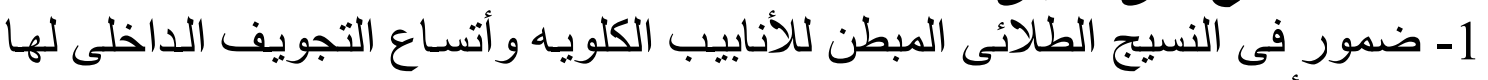

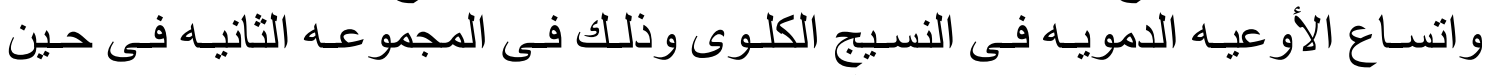

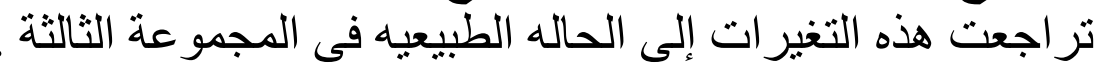

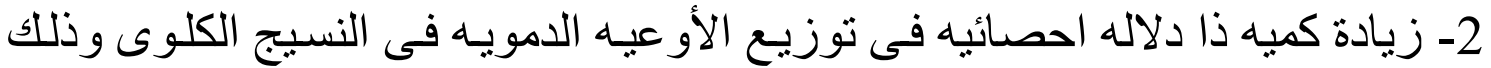

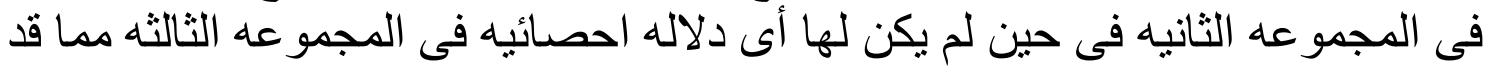

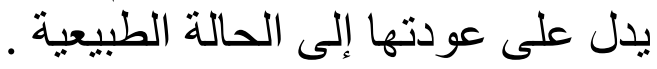

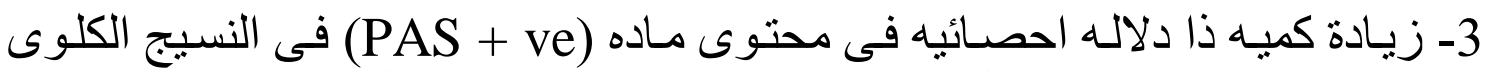

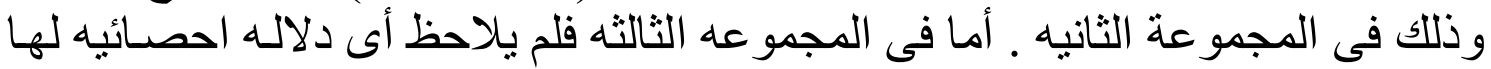

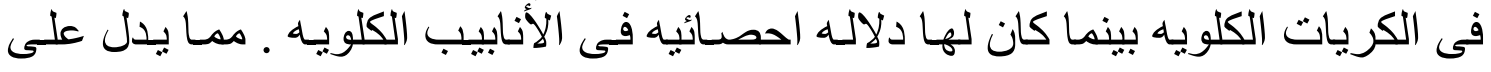

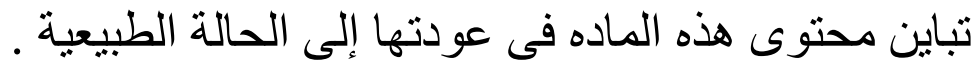


4- عدم حدوث أى تغيير كمى ذى دلاله إحصائيه فى نشاط كل من إنزيمى الفوسئ إنهاتيز الحمضى و السكسينيك دى هيدروجينيز في كل دئ دن المجمو عاله الثانيه و المجمو عه الثنالثه

ويستخلص من هذه الدر اسـة أن حقن مـادة المدروكسى بروجيسترون استيات كوسيلة

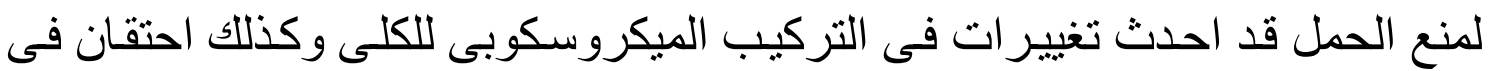

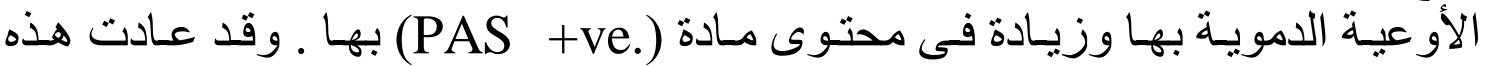

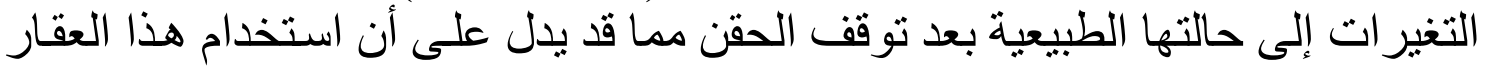

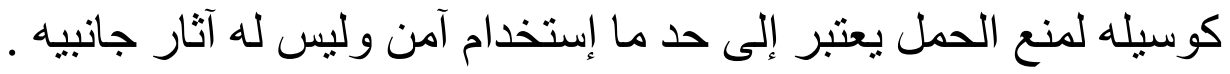

